\title{
Glyburide inhibits the Cryopyrin/Nalp3 inflammasome
}

\author{
Mohamed Lamkanfi, ${ }^{1}$ James L. Mueller, ${ }^{4,5,6}$ Alberto C. Vitari, ${ }^{1}$ Shahram Misaghi, ${ }^{1}$ Anna Fedorova, ${ }^{2}$ Kurt Deshayes, ${ }^{2}$ \\ Wyne P. Lee, ${ }^{3}$ Hal M. Hoffman, ${ }^{4,5,6}$ and Vishva M. Dixit ${ }^{1}$ \\ 'Department of Physiological Chemistry, ${ }^{2}$ Department of Protein Engineering, and ${ }^{3}$ Department of Immunology, Genentech, South San Francisco, CA 94080 \\ ${ }^{4}$ Division of Rheumatology, Allergy, and Immunology, ${ }^{5}$ Department of Pediatrics, and ${ }^{6}$ Ludwig Institute of Cancer Research, School of Medicine, University of California, \\ San Diego, La Jolla, CA 92093
}

西

nflammasomes activate caspase- 1 for processing and secretion of the cytokines interleukin-1 $\beta$ (IL-1 $\beta$ ) and IL-18. Cryopyrin/NALP3/NLRP3 is an essential component of inflammasomes triggered by microbial ligands, danger-associated molecular patterns (DAMPs), and crystals. Inappropriate Cryopyrin activity has been incriminated in the pathogenesis of gouty arthritis, Alzheimer's, and silicosis. Therefore, inhibitors of the Nalp3 inflammasome offer considerable therapeutic promise. In this study, we show that the type 2 diabetes drug glyburide prevented activation of the Cryopyrin inflammasome. Glyburide's cyclohexylurea group, which binds to adenosine triphosphatase (ATP)-sensitive $\mathrm{K}^{+}$ $\left(\mathrm{K}_{\mathrm{ATP}}\right)$ channels for insulin secretion, is dispensable for

\section{Introduction}

Glyburide is the most widely used sulfonylurea drug for the treatment of type 2 diabetes in the United States (Riddle, 2003). The drug works by inhibiting ATP-sensitive $\mathrm{K}^{+}\left(\mathrm{K}_{\mathrm{ATP}}\right)$ channels in pancreatic $\beta$ cells (Ashcroft, 2005). $\mathrm{K}_{\mathrm{ATP}}$ channels are octameric complexes of four Kir6.x (Kir6.1 or Kir6.2) and four sulfonylurea receptor (SUR; SUR1 or SUR2) subunits (Clement et al., 1997). The SUR subunits belong to the ATP-binding cassette (ABC) transporter family (Aguilar-Bryan et al., 1995) and function as a regulatory subunit, endowing the Kir6.x channel with sensitivity to inhibition by sulfonylureas such as glyburide and glipizide (Ashcroft, 2005). In addition to $\mathrm{K}_{\text {ATP }}$ channels, the $\mathrm{ABC}$ transporter ABCA1 was proposed as a putative glyburide

Correspondence to Vishva M. Dixit: Dixit.vishva@gene.com

Abbreviations used in this paper: ABC, ATP-binding cassette; BMDM, bone marrow-derived macrophage; DAMP, danger-associated molecular pattern; FCAS, familial cold-associated autoinflammatory syndrome; IL, interleukin; $\mathrm{K}_{\text {ATP, }}$ ATP-sensitive $\mathrm{K}^{+}$; LPS, lipopolysaccharide; PAMP, pathogen-associated molecular pattern; PBMC, peripheral blood mononuclear cell; SUR, sulfonylurea receptor. inflammasome inhibition. Macrophages lacking $\mathrm{K}_{\text {ATP }}$ subunits or ATP-binding cassette transporters also activate the Cryopyrin inflammasome normally. Glyburide analogues inhibit ATP- but not hypothermia-induced IL-1 $\beta$ secretion from human monocytes expressing familial cold-associated autoinflammatory syndromeassociated Cryopyrin mutations, thus suggesting that inhibition occurs upstream of Cryopyrin. Concurrent with the role of Cryopyrin in endotoxemia, glyburide significantly delays lipopolysaccharide-induced lethality in mice. Therefore, glyburide is the first identified compound to prevent Cryopyrin activation and microbial ligand-, DAMP-, and crystal-induced IL-1 $\beta$ secretion.

target (Hamon et al., 1997). Glyburide's pharmacological properties are summarized in Fig. S1 A.

The cystein protease caspase- 1 mediates the proteolytic maturation of the cytokines interleukin-1 $\beta$ (IL-1 $\beta$ ) and IL-18 after its recruitment in protein complexes termed inflammasomes (Lamkanfi and Dixit, 2009). Cryopyrin/NALP3/NLRP3 is an essential component of inflammasomes triggered by pathogenassociated molecular patterns (PAMPs), danger-associated molecular patterns (DAMPs), and crystalline substances (Kanneganti et al., 2006, 2007; Mariathasan et al., 2006; Sutterwala et al., 2006; Lamkanfi and Dixit, 2009). Inappropriate Cryopyrin activity has been incriminated in the pathogenesis of several diseases, including gouty arthritis, Alzheimer's, and silicosis (Martinon et al., 2006; Cassel et al., 2008; Dostert et al., 2008; Halle et al.,

(c) 2009 Lamkanfi et al. This article is distributed under the terms of an AttributionNoncommercial-Share Alike-No Mirror Sites license for the first six months after the publication date (see http://www.jcb.org/misc/terms.shtml). After six months it is available under a Creative Commons License (Attribution-Noncommercial-Share Alike 3.0 Unported license, as described at http://creativecommons.org/licenses/by-nc-sa/3.0/). 
A
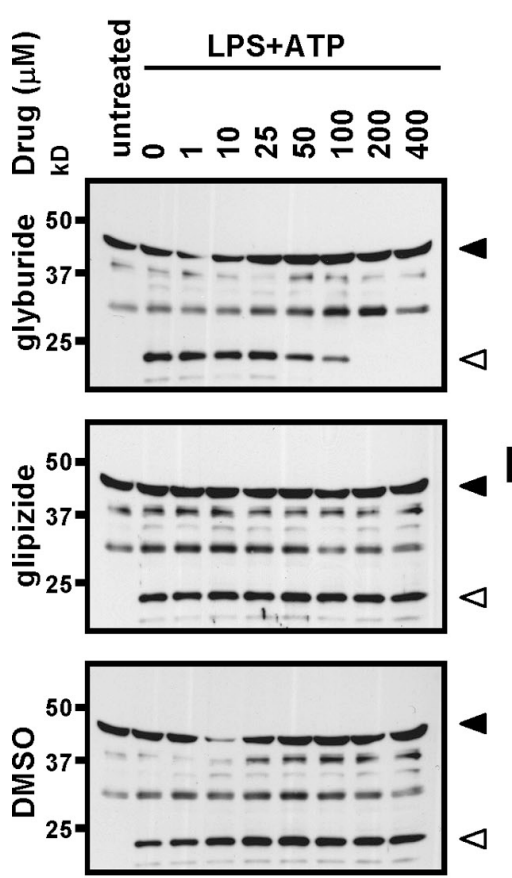

F

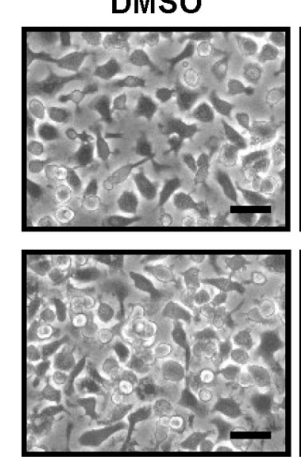

$\mathrm{H}$
B

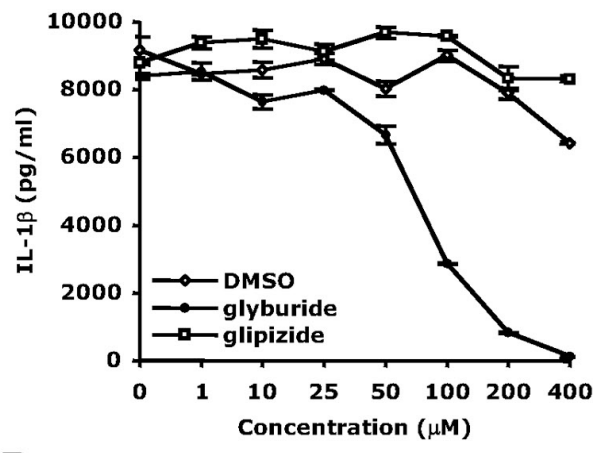

C

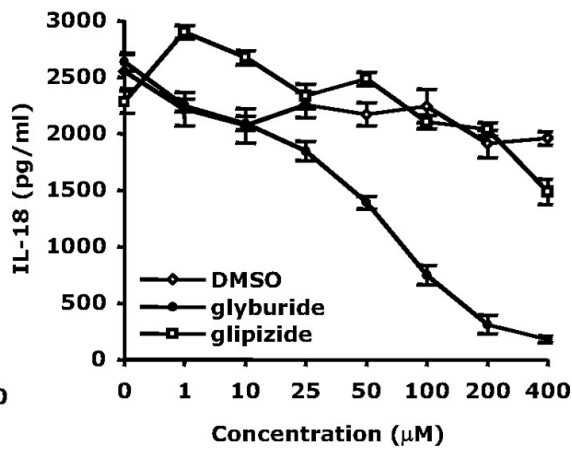

E

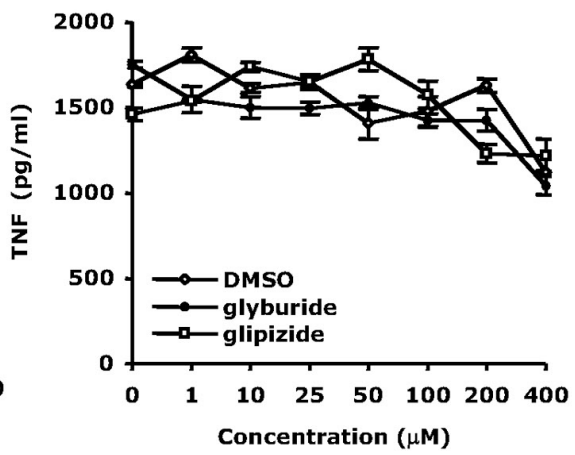

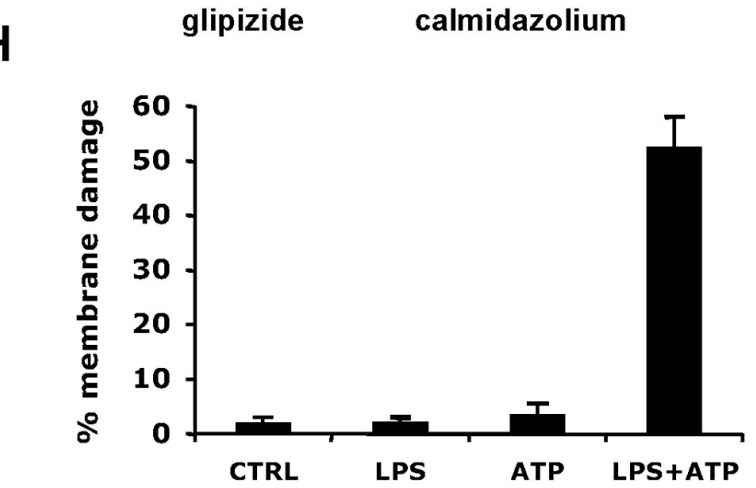

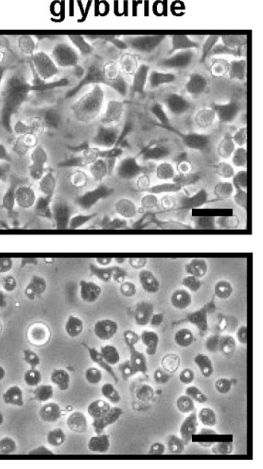

calmidazolium

G

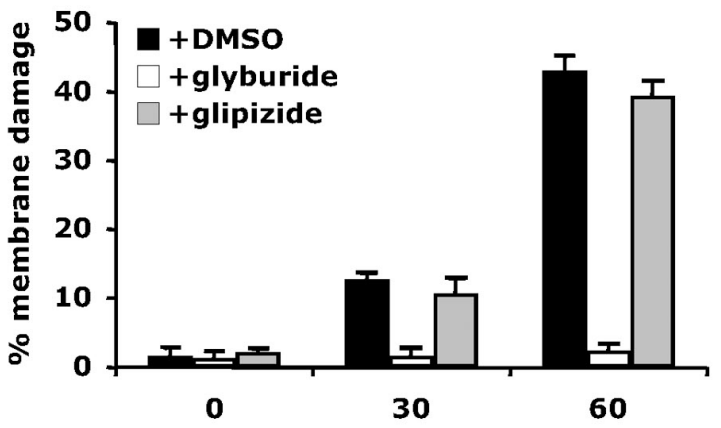

Time post-ATP (min)

I

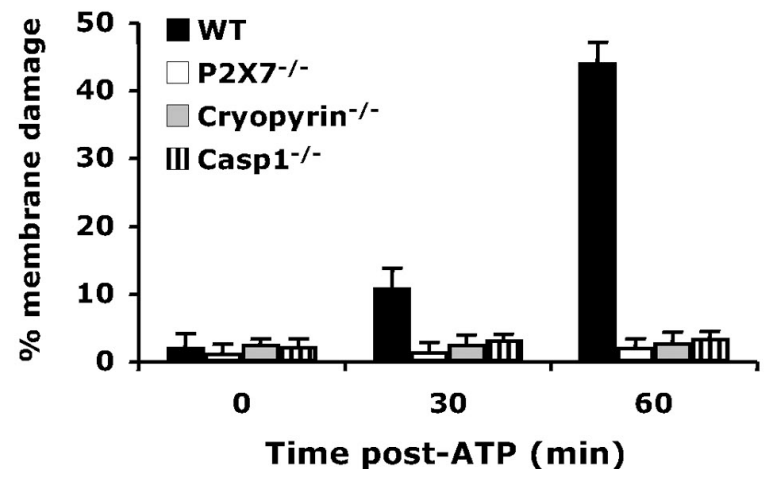

Figure 1. Glyburide inhibits LPS+ATP-induced caspase-1 activation, secretion of IL-1 $\beta$ and IL-18, and macrophage cell death. (A-E) LPS-primed BMDMs were treated with glyburide, glipizide, or DMSO for $15 \mathrm{~min}$ before $5 \mathrm{mM}$ ATP was added for $30 \mathrm{~min}$. Cell extracts were immunoblotted for caspase-1 $(A)$, and culture supernatants were analyzed for secreted IL-1 $\beta$ (B), IL-18 (C), IL-6 (D), and TNF (E). Black arrowheads indicate procaspase-1, and white arrowheads mark the p20 subunit. (F) BMDMs were incubated with $200 \mu \mathrm{M}$ glyburide, $200 \mu \mathrm{M}$ glipizide, $200 \mu M$ DMSO, or $50 \mu M$ calmidazolium for $2 \mathrm{~h}$ before brightfield photographs were taken. (G) LPS-primed BMDMs were treated with 200 pM glyburide, glipizide, or DMSO for 15 min followed by 5 mM ATP for the indicated durations. Membrane damage was measured using Live/Dead assay. Bars, 20 rm. (H) BMDMs were left untreated (CTRL), stimulated with $10 \mu \mathrm{g} / \mathrm{ml}$ LPS for $3 \mathrm{~h}$, treated with $5 \mathrm{mM}$ ATP for $1 \mathrm{~h}$, or treated with LPS and ATP. Membrane damage was measured using Live/Dead assay. 
2008; Hornung et al., 2008), so inhibitors of the Cryopyrin inflammasome offer considerable therapeutic promise.

In this study, we show that glyburide prevented activation of the Cryopyrin inflammasome by a variety of stimuli. Concurrent with the role of Cryopyrin in endotoxemia, glyburide delayed lipopolysaccharide (LPS)-induced lethality in mice. Therefore, glyburide is the first compound identified to act upstream of Cryopyrin to prevent PAMP-, DAMP-, and crystal-induced IL-1 $\beta$ secretion.

\section{Results and discussion}

\section{Glyburide inhibits LPS+ATP-induced caspase-1 activation, IL-1 1 secretion, and macrophage death}

Glyburide prevents LPS+ATP-induced secretion of IL-1 $\beta$ from human and murine macrophages (Hamon et al., 1997; Laliberte et al., 1999; Perregaux et al., 2001) and from murine Schwann cells (Marty et al., 2005). To determine whether caspase-1 activation is impaired by glyburide, LPS-primed bone marrowderived macrophages (BMDMs) were incubated with glyburide for $15 \mathrm{~min}$ before ATP was added for another $30 \mathrm{~min}$. In contrast to the related sulfonylurea glipizide, glyburide inhibited caspase-1 processing in a dose-dependent fashion (Fig. $1 \mathrm{~A}$ ), and this prevented secretion of the caspase-1-dependent cytokines IL-1 $\beta$ (Fig. 1 B) and IL-18 (Fig. 1 C). Secretion of IL-6 (Fig. 1 D) and TNF (Fig. 1 E) was not impaired by glyburide, ruling out a general defect in macrophage responsiveness. Inhibition was evident up to $3 \mathrm{~h}$ post-ATP (Fig. S1 B), indicating that glyburide did not merely delay caspase-1 activation.

Significantly, BMDMs cultured for $3 \mathrm{~h}$ in glyburide, glipizide, or DMSO looked morphologically normal (Fig. $1 \mathrm{~F}$ ) and displayed no significant membrane damage (Fig. S1 C). As a positive control, macrophage death was induced with the calmodulin inhibitor calmidazolium (Fig. $1 \mathrm{~F}$ and Fig. S1 C). Inhibition of caspase- 1 activation by glyburide was reversible because caspase-1 was activated if glyburide was removed from the culture medium before ATP addition (Fig. S1 D). Glyburide also blocked the rapid, caspase-1-dependent cell death that occurs when BMDMs are treated with LPS and ATP (Fig. 1, G-I). As expected, glipizide and DMSO did not prevent this death. Of note, neither LPS nor ATP alone affected BMDM viability (Fig. $1 \mathrm{H}$ ). Like caspase- $1^{-/-}$ BMDMs, cells lacking the $\mathrm{P}_{2} \mathrm{X}_{7}$ receptor or Cryopyrin were not killed by LPS+ATP (Fig. 1 I). These results demonstrate that the Cryopyrin inflammasome is essential for LPS+ATP-induced macrophage death and that glyburide inhibits LPS+ATP-induced caspase- 1 activation, IL-1 $\beta$ secretion, and macrophage death.

\section{Glyburide's sulfonyl and benzamido groups are required for optimal inhibition of the \\ Cryopyrin inflammasome}

Glyburide inhibits $\mathrm{K}_{\mathrm{ATP}}$ channels on pancreatic $\beta$ cells. Its cyclohexylurea group is necessary for high affinity binding to SUR1 (Meyer et al., 1999), which is the SUR subunit of these $\mathrm{K}_{\text {ATP }}$ channels. Interestingly, the cyclohexylurea group (Fig. 2 A, compound G1) was dispensable for inhibition of LPS+ATP-induced caspase-1 activation (Fig. 2 B) and IL-1 $\beta$ secretion (Fig. 2 C). As expected, glyburide and compound G1 did not affect IL-6 secretion (Fig. 2 D). Glipizide also contains a cyclohexylurea group (Fig. 2 A) and inhibits SUR1-containing $\mathrm{K}_{\mathrm{ATP}}$ channels, but it failed to inhibit caspase-1 activation (Fig. 2 B). These data suggest that inhibition of the Cryopyrin inflammasome is independent of SUR1-containing $\mathrm{K}_{\mathrm{ATP}}$ channels.

Additional structure activity experiments demonstrated that both the benzamido and sulfonyl groups of glyburide (Fig. 2 A, compounds G2-G4) were required for optimal inhibition. Analogue G2 comprising only the benzamido group (Fig. 2 A, compound G2) inhibited LPS+ATP-induced caspase-1 activation (Fig. 2 E) and IL-1 $\beta$ secretion (Fig. 2 F), albeit less effectively than compound G1. Thus, the benzamido group contributes but is not sufficient for optimal inhibition. Indeed, a G1 analogue lacking the benzamido group (Fig. 2 A, compound G3) did not affect caspase- 1 activation and IL-1 $\beta$ secretion (Fig. 2, $\mathrm{E}$ and $\mathrm{F}$ ). In addition to the benzamido group, the sulfonyl moiety is required for optimal inhibition, as deletion of the sulfonyl group from compound G1 (Fig. 2 A, compound G4) was less effective at inhibiting caspase- 1 activation and IL- $1 \beta$ secretion (Fig. 2, E and F). Like glyburide, compounds G1-G4 permitted normal IL-6 secretion (Fig. 2 G), demonstrating the specificity of these results.

\section{Glyburide inhibits the Cryopyrin inflammasome downstream of the $\mathrm{P} \mathbf{X}_{7}$ receptor}

Like ATP, the cation ionophore nigericin engages the Cryopyrin inflammasome (Mariathasan et al., 2006), but nigericin signals independently of the $\mathrm{P}_{2} \mathrm{X}_{7}$ receptor (Fig. S1, E-G; Solle et al., 2001). Glyburide potently blocked LPS+nigericin-induced caspase-1 activation (Fig. 3 A). As expected, glipizide and DMSO vehicle did not prevent LPS+nigericin-induced caspase-1 activation. Notably, substituting lipid A, lipoteichoic acid, peptidoglycan, or Pam3-CSK4 for LPS did not prevent glyburide from inhibiting caspase-1 activation (Fig. 3 B).

In agreement with previous studies (Cassel et al., 2008; Dostert et al., 2008; Hornung et al., 2008), silica and the lysosomotrophic molecule H-LL-OMe also promoted Cryopyrindependent caspase- 1 activation and IL- $1 \beta$ secretion in LPS-primed BMDMs (Fig. S2, A and B). Caspase-1 activation and IL-1 $\beta$ secretion in response to these stimuli were independent of the $\mathrm{P}_{2} \mathrm{X}_{7}$ receptor (Fig. S2, C and D) but required TLR4 signaling (Fig. S2 E). Glyburide effectively blocked caspase-1 activation and IL-1 $\beta$ secretion by these stimuli too (Fig. 3, C and D). These data suggest that glyburide targets a signaling component downstream of the $\mathrm{P} 2 \mathrm{X}_{7}$ receptor. We first considered the hemichannel pannexin-1, which was proposed to signal both LPS+ATPand LPS+nigericin-induced caspase- 1 activation (Pelegrin and

(I) LPS-primed BMDMs from wild-type (WT), P2X $\mathrm{X}_{7^{-1-}}$, Cryopyrin $^{-1-}$, and caspase-1 $1^{-1-}$ mice were treated with 5 mM ATP for the indicated durations. Membrane damage was measured with Live/Dead assay. Cytokine and cell death data represent the mean \pm SD of triplicate samples from a single experiment, and all results are representative of at least three independent experiments. 
A

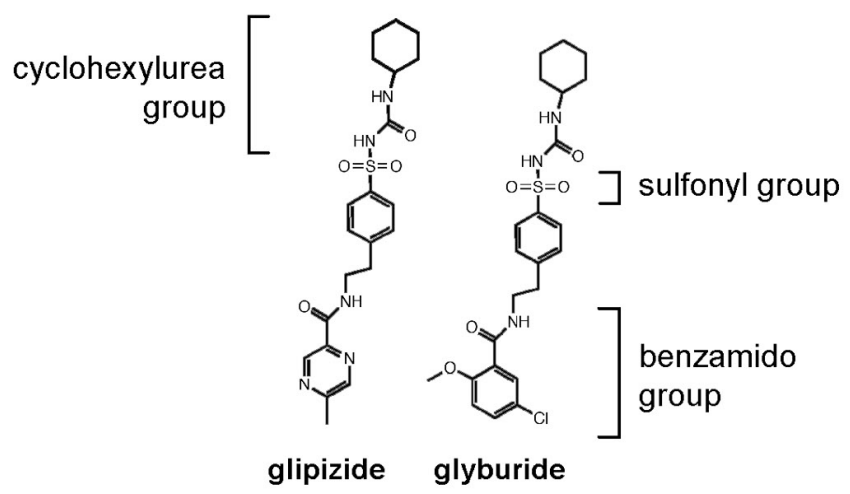<smiles>COC1CCCC1C(=O)NCC1CCC(O)CC1CO</smiles>

G1

C

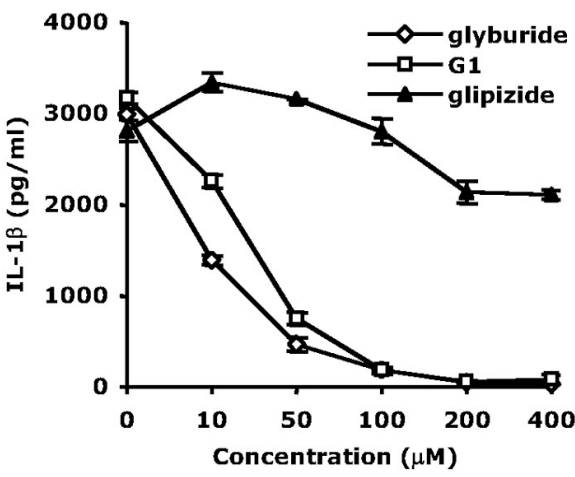

D

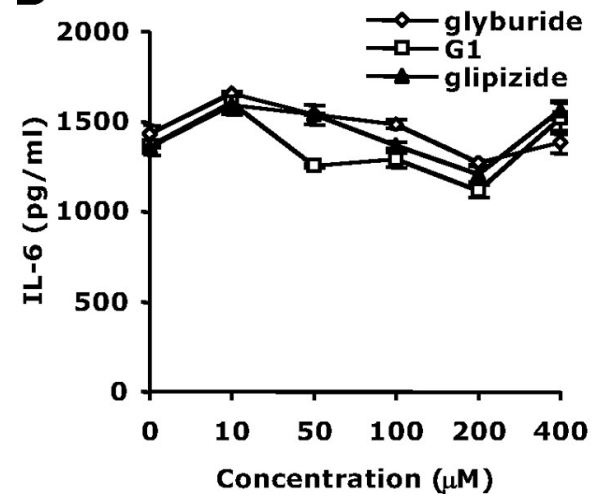

B
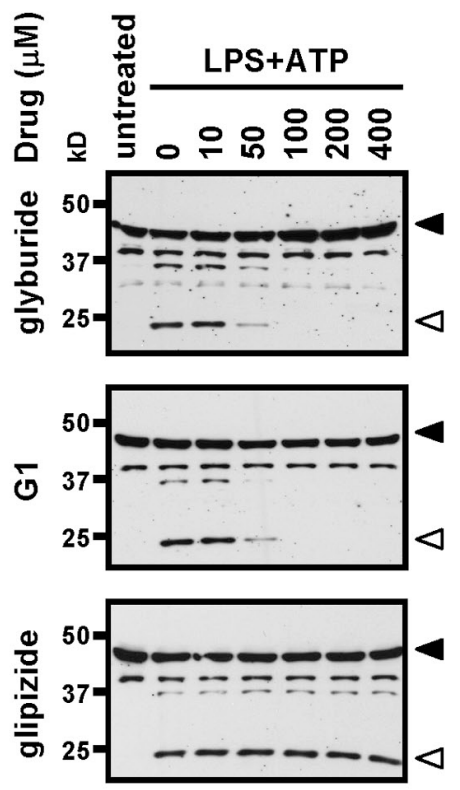

$\mathbf{F}$

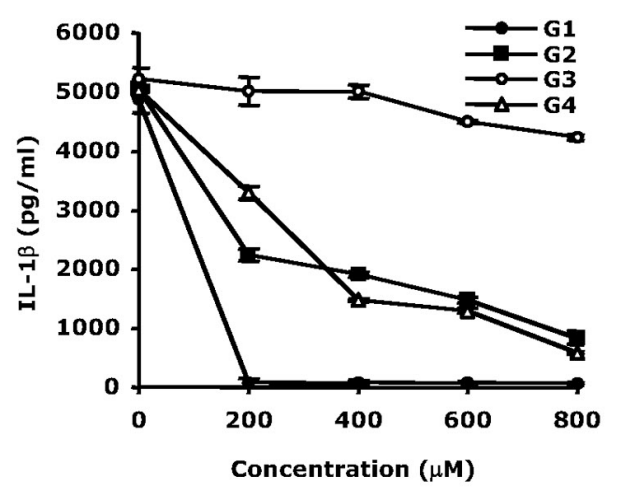

$\mathbf{G}$
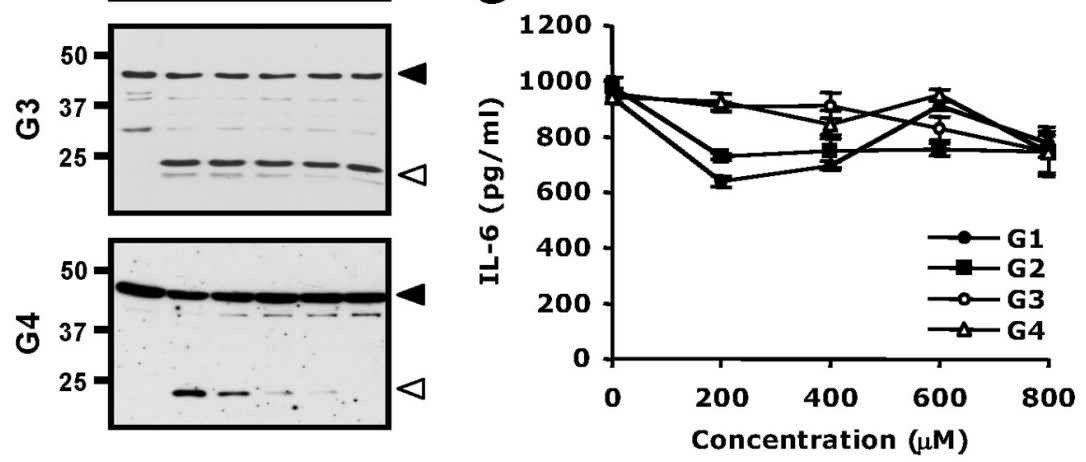

Figure 2. Glyburide's cyclohexylurea moiety is dispensable for inflammasome inhibition. (A) Chemical structure of glyburide, glipizide, and glyburide-derived analogues G1-G4. (B-G) LPS-primed BMDMs were treated with glyburide, glipizide, or analogues G1-G4 for 15 min before 5 mM ATP was added for 30 min. Cell extracts were immunoblotted for caspase-1 (B and E), and culture supernatants were analyzed for secreted IL-1 $\beta$ (C and F) and IL-6 (D and G). Black arrowheads indicate procaspase-1, and white arrowheads mark the p20 subunit. Cytokine data represent the mean \pm SD of triplicate samples from a single experiment, and all results are representative of at least three independent experiments. 
A
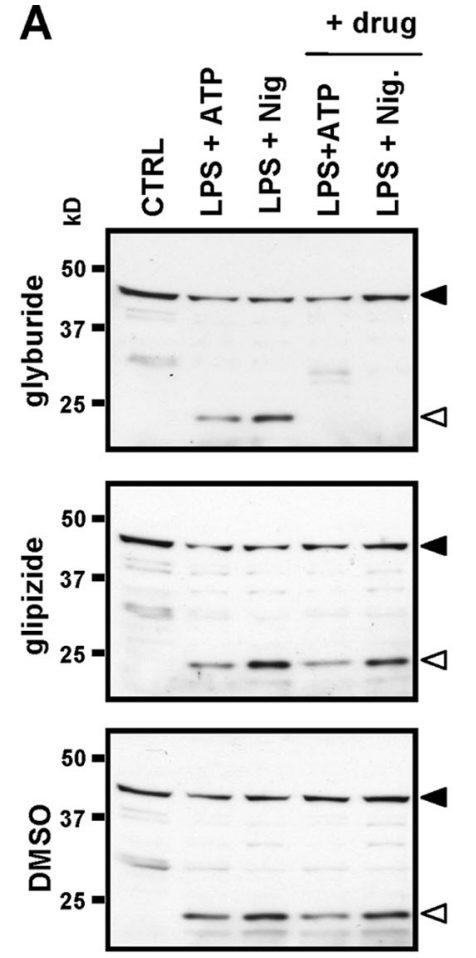

$\mathbf{E}$

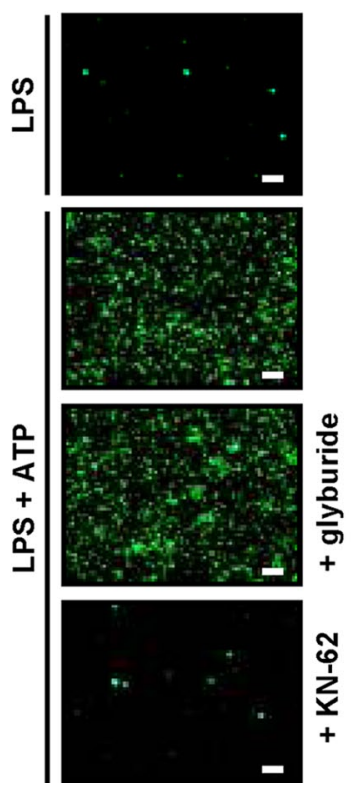

B

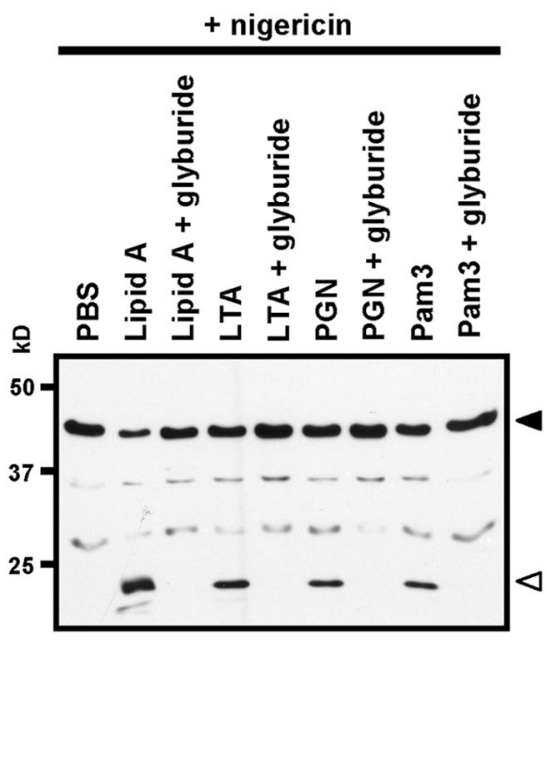

$\mathbf{F}$
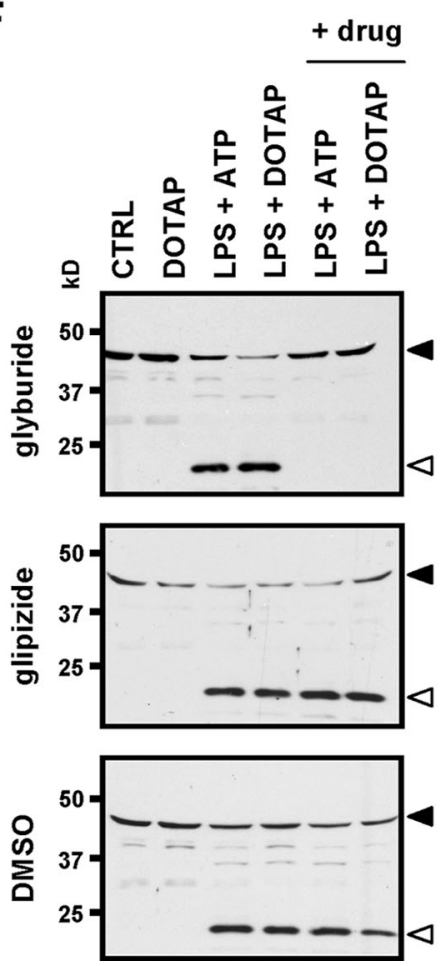

C
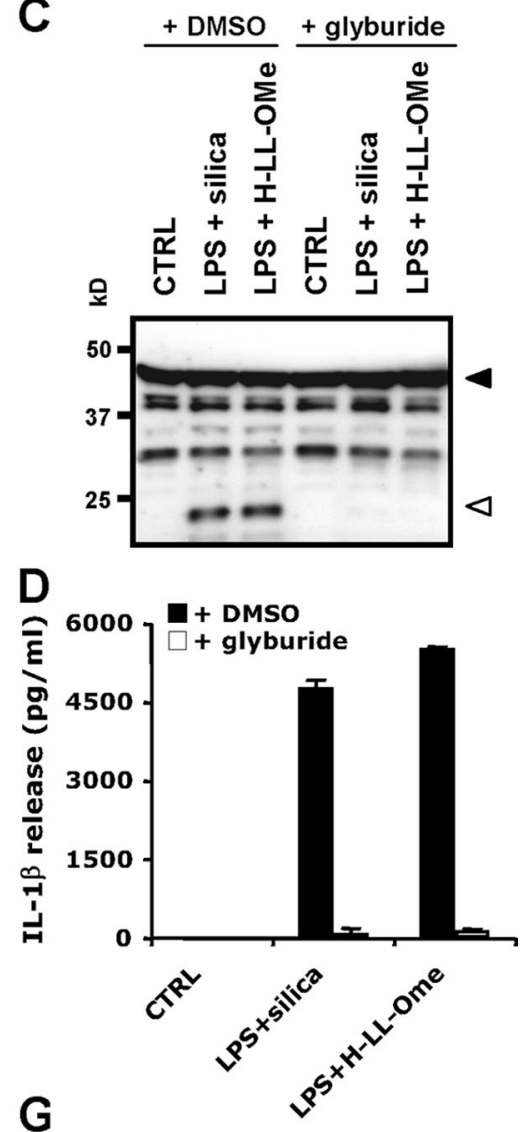

G

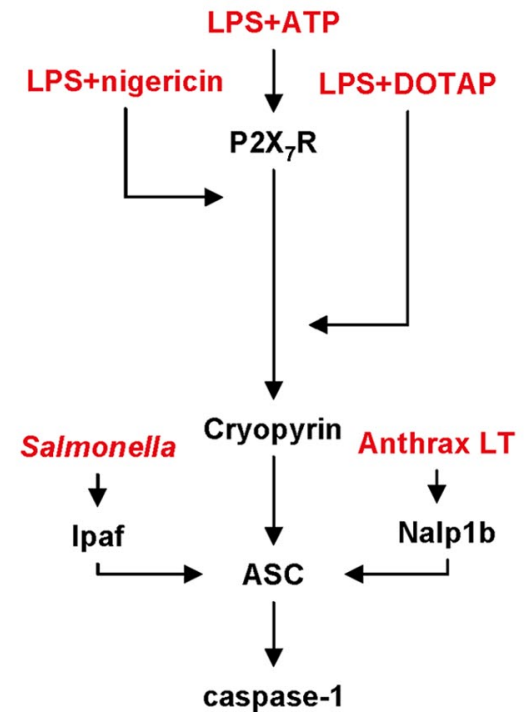

Figure 3. Glyburide inhibits PAMP-, DAMP-, and crystal-induced activation of the Cryopyrin inflammasome. (A) LPS-primed BMDMs were incubated with $200 \mu M$ glyburide, glipizide, or DMSO for $15 \mathrm{~min}$ before $20 \mu \mathrm{M}$ nigericin was added for $30 \mathrm{~min}$. Cell extracts were immunoblotted for caspase-1. (B) BMDMs were stimulated with the indicated PAMPs for $3 \mathrm{~h}$, incubated with $200 \mu \mathrm{M}$ glyburide for 15 min, and stimulated with $20 \mu \mathrm{M}$ nigericin for 30 min. Cell extracts were immunoblotted for caspase-1. (C and D) LPS-primed BMDMs were incubated with $200 \mu \mathrm{M}$ glyburide or DMSO for $15 \mathrm{~min}$ before $500 \mu \mathrm{g} / \mathrm{ml} \mathrm{silica}$ or $1 \mathrm{mM}$ of the lysosomotrophic peptide H-LL-OMe was added for $3 \mathrm{~h}$. Cell extracts were immunoblotted for caspase-1 (C), and culture supernatants were analyzed for secreted IL-1 $\beta$ (D). (E) LPS-primed BMDMs were left untreated or incubated with $200 \mu \mathrm{M}$ glyburide or $10 \mu \mathrm{M} \mathrm{KN}-62$ for 15 min. $2 \mu M$ YoPro-1 was subsequently added, and its uptake was visualized before and after a 5-min ATP pulse. Bars, 50 jm. (F) BMDMs were left untreated (CTRL), transfected with DOTAP alone for $4 \mathrm{~h}$, stimulated with $10 \mu \mathrm{g} / \mathrm{ml}$ LPS for $3 \mathrm{~h}$ and subsequently with $5 \mathrm{mM}$ ATP (LPS+ATP), or transfected with DOTAP and $30 \mu \mathrm{g} / \mathrm{ml}$ LPS for $4 \mathrm{~h}$ (DOTAP+LPS) in the presence or absence of $200 \mu \mathrm{M}$ glyburide, glipizide, or DMSO. Cell extracts were immunoblotted for caspase-1. (G) Overview and mapping of inflammasome-activating stimuli and upstream signaling pathways. Black arrowheads indicate procaspase-1, and white arrowheads mark the p20 subunit. Cytokine data represent the mean \pm SD of triplicate samples from a single experiment, and all results are representative of at least three independent experiments. 
A
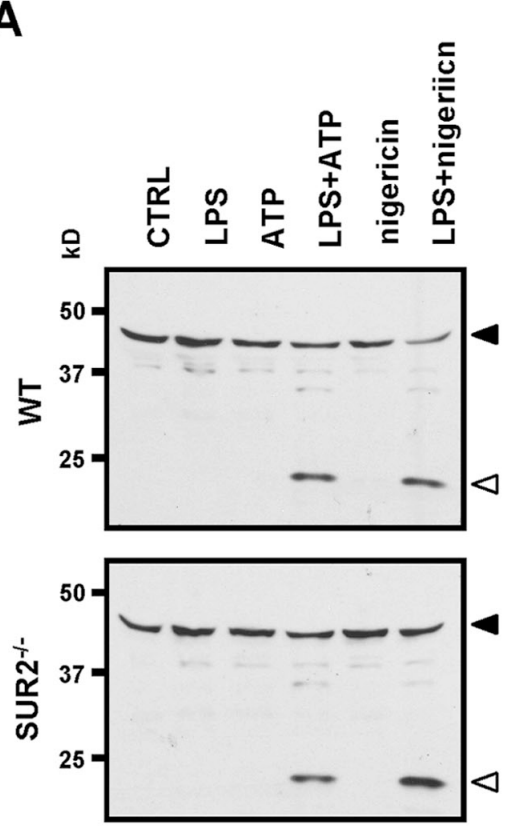

B

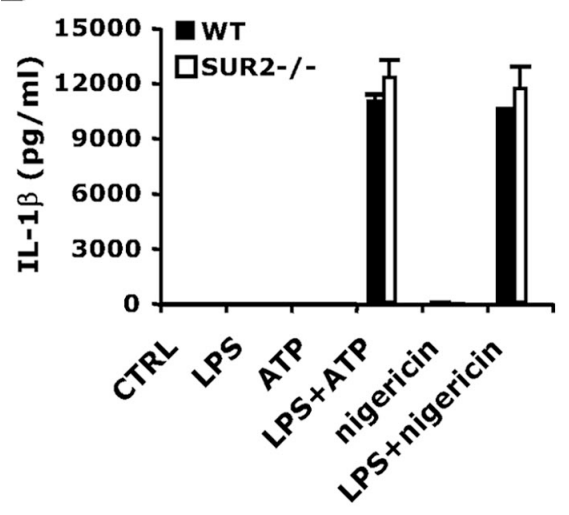

F

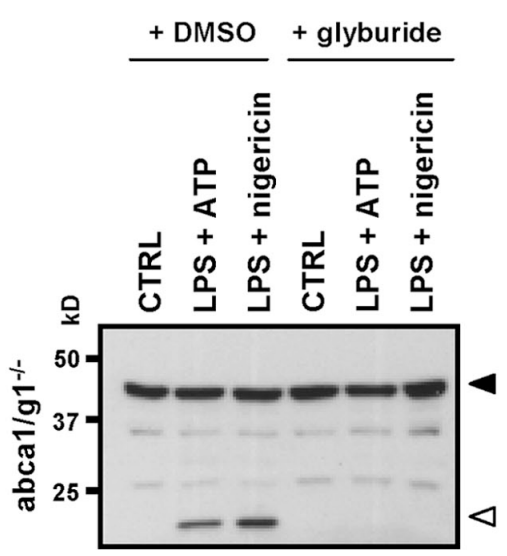

C
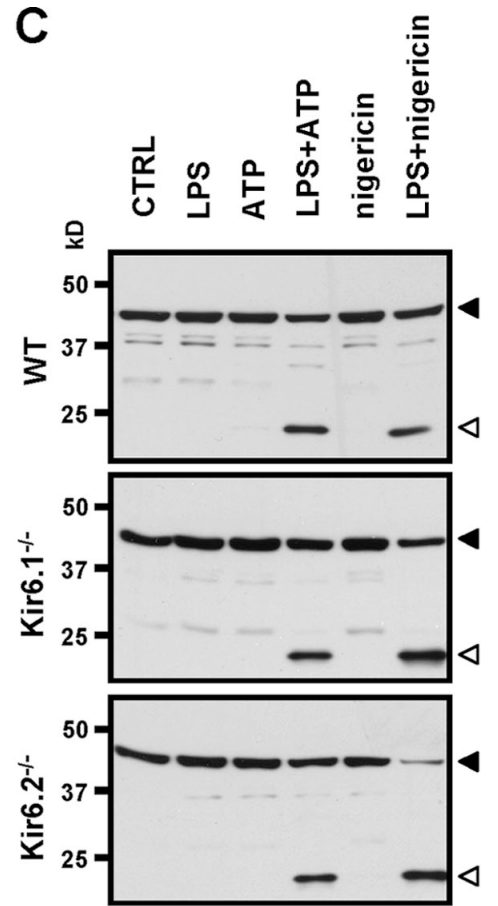

D
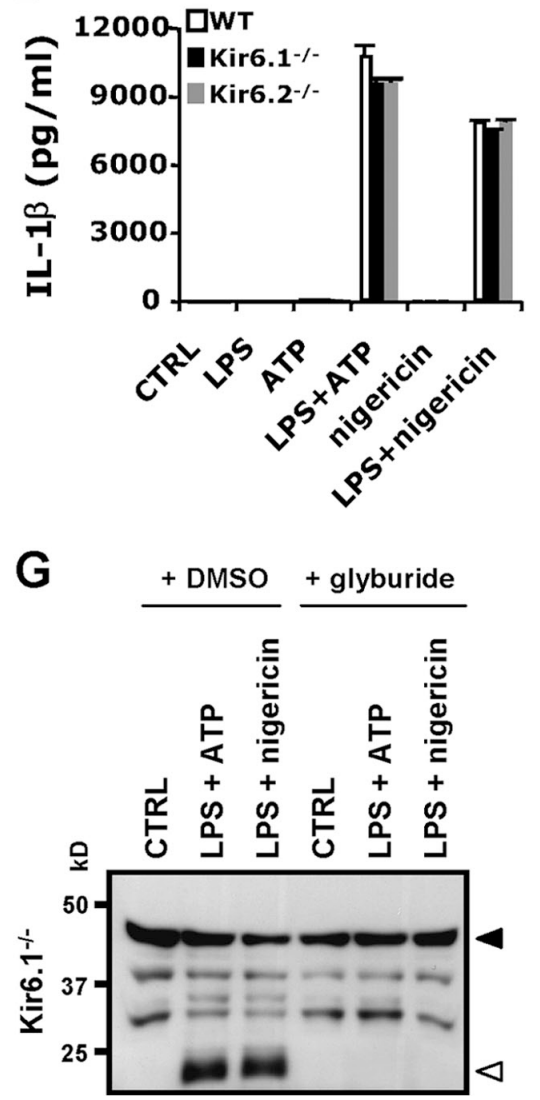

E
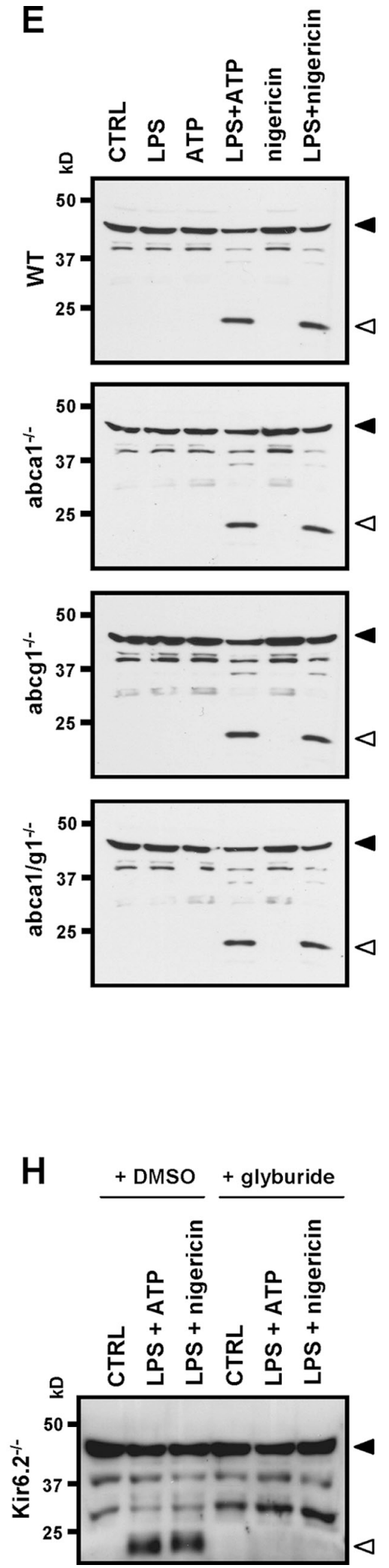

Figure 4. $\mathrm{K}_{\mathrm{ATP}}$ channels and $\mathrm{ABC}$ transporters are dispensable for activation of the Cryopyrin inflammasome. (A-E) BMDMs from wild-type (WT) and

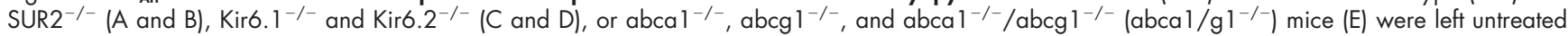
(CTRL), stimulated with $10 \mu \mathrm{g} / \mathrm{ml} \mathrm{LPS} \mathrm{for} 3 \mathrm{~h}$, treated with $5 \mathrm{mM}$ ATP or $20 \mu \mathrm{M}$ nigericin for $30 \mathrm{~min}$, or stimulated with LPS and treated with ATP (LPS+ATP) or nigericin (LPS+nigericin). Cell extracts were immunoblotted for caspase-1 (A, C, and E), and culture supernatants were analyzed for secreted IL-1 $\beta$

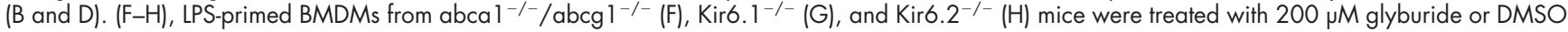
for $15 \mathrm{~min}$ before $5 \mathrm{mM}$ ATP or $20 \mu \mathrm{M}$ nigericin was added for an additional $30 \mathrm{~min}$. Cell extracts were immunoblotted for caspase-1. Black arrowheads indicate procaspase-1, and white arrowheads mark the p20 subunit. Cytokine data represent the mean \pm SD of triplicate samples from a single experiment, and all results are representative of three independent experiments. 
Surprenant, 2006, 2007; Kanneganti et al., 2007). Pannexin-1 forms a nonselective pore for molecules $<1 \mathrm{kD}$, such as the fluorescent dye YoPro-1, within seconds to minutes of $\mathrm{P} 2 \mathrm{X}_{7}$ receptor stimulation (Pelegrin and Surprenant, 2006, 2007; Locovei et al., 2007). Unlike the $\mathrm{P} 2 \mathrm{X}_{7}$ receptor inhibitor $\mathrm{KN}-62$, glyburide did not prevent ATPinduced YoPro-1 uptake into LPS-primed macrophages (Fig. 3 E), suggesting that pannexin-1 is not inhibited by glyburide. Concurrently, glyburide inhibited caspase- 1 activation by LPS+DOTAP (Fig. 3 F), a stimulus that engages the Cryopyrin inflammasome independently of the $\mathrm{P} 2 \mathrm{X}_{7}$ receptor and pannexin-1 (Kanneganti et al., 2007). Collectively, these results indicate that glyburide inhibits engagement of the Cryopyrin inflammasome by diverse stimuli and that inhibition occurs downstream of the $\mathrm{P} 2 \mathrm{X}_{7}$ receptor (Fig. $3 \mathrm{G}$ ).

$K_{\text {ATP }}$ channels and ABC transporters are dispensable for activation of the Cryopyrin inflammasome

The structure-activity relationship experiments (Fig. 2) suggest that glyburide inhibits the Cryopyrin inflammasome independently of SUR1-containing $\mathrm{K}_{\mathrm{ATP}}$ channels. Certain tissues such as heart and muscle express SUR2 instead of SUR1 $\mathrm{K}_{\text {ATP }}$ channels. However, SUR2 ${ }^{-1-}$ BMDMs activated caspase- 1 and secreted normal amounts of IL-1 $\beta$ in response to LPS+ATP and LPS+nigericin (Fig. 4, A and B). In addition, BMDMs from Kir6. $1^{-l-}$ and Kir6. $2^{-l-}$ mice also demonstrated normal LPS+ATPand LPS+nigericin-induced caspase- 1 activation (Fig. 4 C) and IL-1 $\beta$ secretion (Fig. 4 D). These results show that $\mathrm{K}_{\mathrm{ATP}}$ channels are not required for activation of the Cryopyrin inflammasome.

Previous studies also suggested that glyburide and the ABC transporter inhibitor DIDS (4,4'-diisothiocyanatostilbene-2,2'disulfonic acid disodium) target ABCA1 to inhibit LPS+ATPinduced IL-1 $\beta$ secretion (Hamon et al., 1997; Marty et al., 2005). We confirmed that DIDS inhibited LPS+ATP-induced IL-1 $\beta$ secretion in a dose-dependent manner (Fig. S3 A). However, DIDS also inhibited $\mathrm{P}_{2} \mathrm{X}_{7}$ receptor-mediated currents (Ma et al., 2009) and caspase-1 activation (Fig. S3 B), suggesting that the drug prevents IL- $1 \beta$ secretion by directly antagonizing the $\mathrm{P} 2 \mathrm{X}_{7}$ receptor rather than ABCA1. Concurrently, BMDMs from mice lacking ABCA1 and/or ABCG1 activated caspase-1 normally in response to LPS+ATP and LPS+nigericin (Fig. 4 E). Caspase-1 activation also was normal in macrophages lacking the glyburide receptor cystic fibrosis transmembrane conductance regulator (unpublished data).

To complement these experiments, we analyzed whether glyburide prevented caspase-1 activation in macrophages lacking $\mathrm{ABC}$ transporters or $\mathrm{K}_{\mathrm{ATP}}$ channels. As in wild-type macrophages (Fig. 1 A), glyburide abolished LPS+ATP- and LPS+nigericininduced caspase-1 activation in macrophages lacking ABCA1 and ABCG1 (Fig. 4 F) or the $\mathrm{K}_{\text {ATP }}$ channel subunits Kir6.1 (Fig. 4 G) and Kir6.2 (Fig. $4 \mathrm{H}$ ). In summary, these experiments indicate that known targets of glyburide are dispensable for activation of the Cryopyrin inflammasome.

Inflammasome inhibition occurs upstream of Cryopyrin

Ipaf rather than Cryopyrin is critical for inflammasome assembly and caspase-1 activation by Salmonella typhimurium infection
(Mariathasan et al., 2004). Interestingly, caspase-1 activation in S. typhimurium-infected BMDMs was not affected by glyburide (Fig. 5 A). Furthermore, anthrax lethal toxin, which engages the NALP1b inflammasome (Boyden and Dietrich, 2006), also activated caspase-1 normally in the presence of glyburide (Fig. 5 B). Concurrently, glyburide did not affect caspase-1 activity in vitro (Fig. 5 C). These data suggest that glyburide works upstream of caspase-1 and ASC, the shared adaptor in the Cryopyrin, Ipaf, and NALP1b inflammasomes (Fig. $3 \mathrm{G}$ ).

We next studied the affect of glyburide and compound G1 on the ATPase activity of Cryopyrin, which is required for caspase-1 activation and IL-1 $\beta$ secretion (Duncan et al., 2007). Neither glyburide nor compound G1 reduced the ATPase activity of recombinant Cryopyrin (Fig. 5, D and E; and Fig. S3, C and D), placing glyburide action upstream of Cryopyrin. We sought confirmatory evidence using human peripheral blood mononuclear cells (PBMCs) from individuals afflicted with familial cold-associated autoinflammatory syndrome (FCAS), a disorder resulting from a temperature-sensitive (L353P) mutation within Cryopyrin (Hoffman et al., 2001). Similar to LPS+ATP at $37^{\circ} \mathrm{C}$, cold-induced conformational changes in FCAS monocytes are presumed to assemble the Cryopyrin inflammasome at the permissive temperature of $32^{\circ} \mathrm{C}$. It is worth noting that FCAS monocytes secreted a small amount of IL- $1 \beta$ at $37^{\circ} \mathrm{C}$ in response to either ATP or LPS alone (Fig. S3 E), suggesting that FCAS monocytes are hyperresponsive. Compound G1 inhibited LPS+ATP-induced IL- $1 \beta$ secretion at 37 and $32^{\circ} \mathrm{C}$ (Fig. $5 \mathrm{~F}$ and not depicted) but did not prevent cold-induced IL- $1 \beta$ secretion from FCAS PBMCs at $32^{\circ} \mathrm{C}$ (Fig. $5 \mathrm{G}$ ). Therefore, compound G1 and glyburide likely act upstream of Cryopyrin in inhibiting caspase-1 activation. We also assessed the affect of glyburide on LPS-induced lethality in mice based on the observation that Cryopyrin-deficient mice are resistant to LPS-induced lethality (Mariathasan et al., 2006; Sutterwala et al., 2006). Although $90 \%$ of vehicle-treated mice died within $20 \mathrm{~h}$ after LPS dosage, all mice in the glyburide-treated group were alive at this time point (Fig. $5 \mathrm{H}$ ). Mortality in the glyburide-treated arm was significantly delayed $(\mathrm{P}<0.0001)$, but in line with glyburide's relatively short half-life in vivo $(\sim 1 \mathrm{~h}$; unpublished data), the mice eventually succumbed to endotoxic shock.

Collectively, these results demonstrate that glyburide acts upstream of Cryopyrin and downstream of the $\mathrm{P} 2 \mathrm{X}_{7}$ receptor to block Cryopyrin-dependent inflammasome activation by PAMPs, DAMPs, and crystalline substances. These results may have significant therapeutic ramifications for the treatment of gouty arthritis, silicosis, and Alzheimer's, in which excessive Cryopyrin-dependent IL-1 $\beta$ production was proposed as a major cause of pathology (Cassel et al., 2008; Dostert et al., 2008; Halle et al., 2008; Hornung et al., 2008).

\section{Materials and methods}

Mice and macrophages

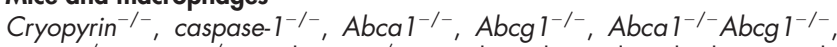
Kir6. $1^{-1-}$, Kir6. $2^{-1-}$, and SUR2 $2^{-1-}$ mice have been described previously (Miki et al., 1998, 2002; Schott et al., 2004; Mariathasan et al., 2006; Stoller et al., 2007; Yvan-Charvet et al., 2008). $P 2 X_{7}^{-1-}$ mice were obtained from Lexicon Pharmaceuticals. Mice were housed in a pathogen-free facility. All experiments were conducted in compliance with the National Institutes of Health Guide for the Care and Use of Laboratory Animals and 
A

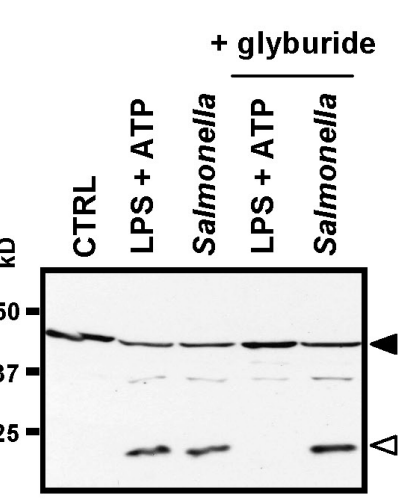

D

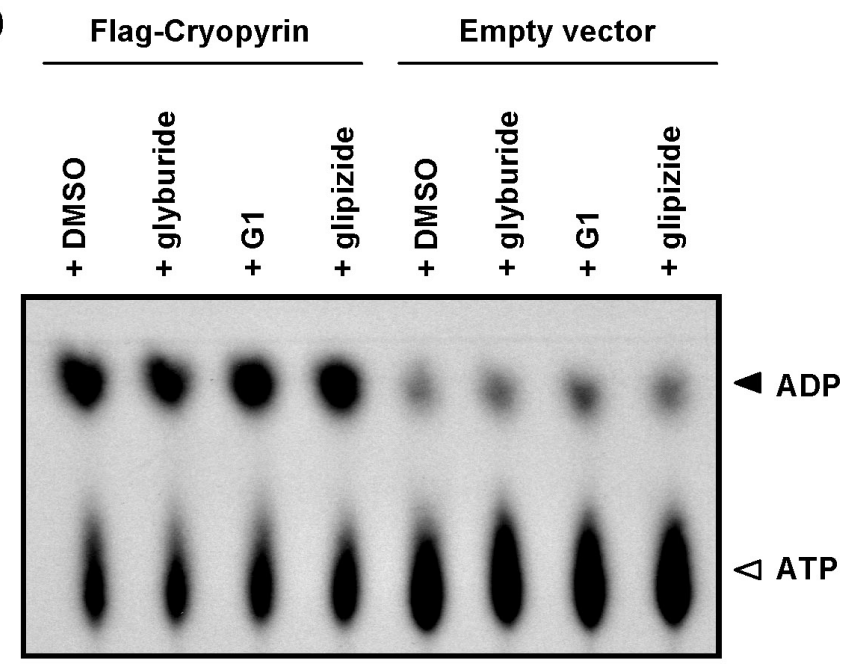

F

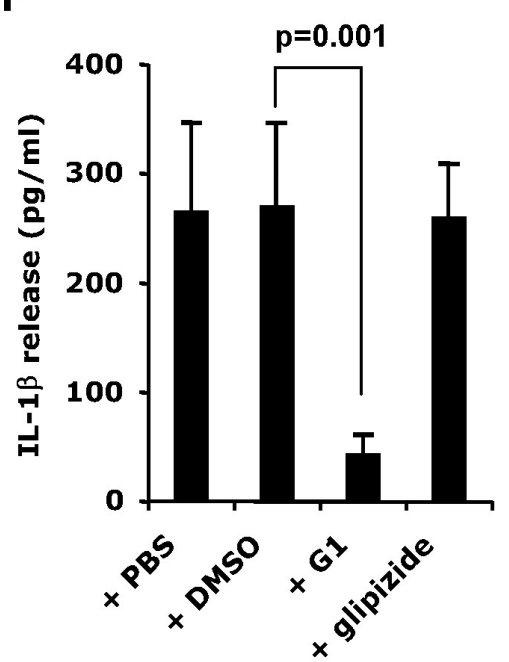

B

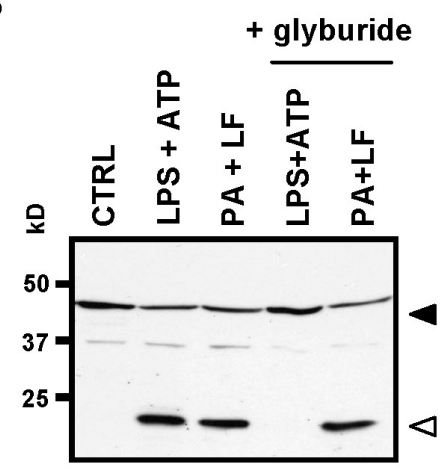

E
G
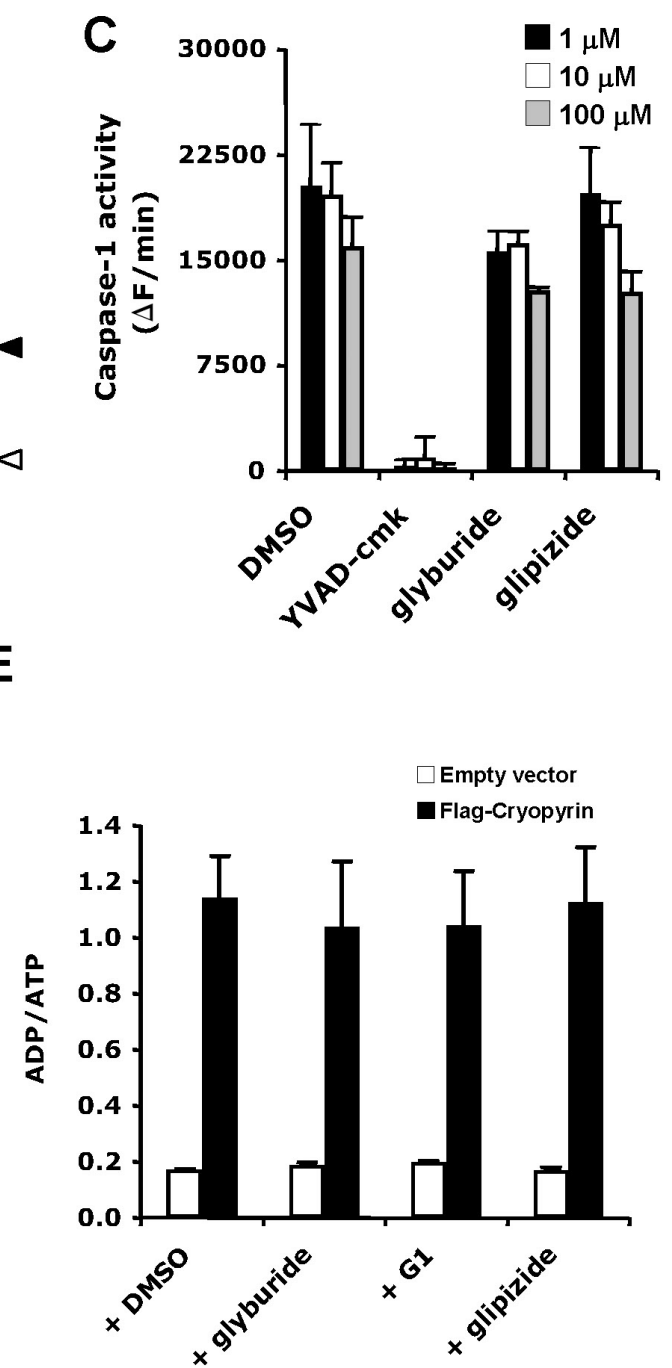

$\mathrm{H}$
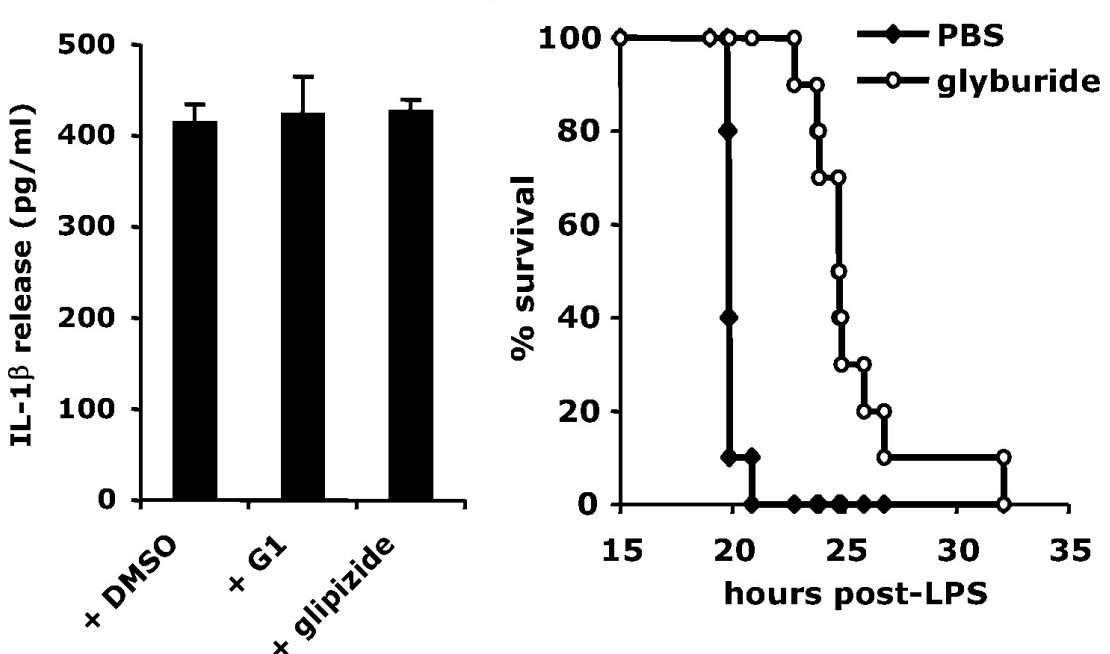

Figure 5. Glyburide inhibits the inflammasome upstream of Cryopyrin. (A and B) BMDMs from C57BL/6 (A) or BALB/c mice (B) were stimulated with $10 \mathrm{\mu g} / \mathrm{ml}$ LPS for $3 \mathrm{~h}$ and treated with $5 \mathrm{mM}$ ATP for $30 \mathrm{~min}$ (LPS+ATP), infected with $S$. typhimurium for $4 \mathrm{~h}$, or treated with $10 \mu \mathrm{g} / \mathrm{ml} \mathrm{anthrax} \mathrm{lethal} \mathrm{toxin}$ (PA+LF) for $4 \mathrm{~h}$ in the presence or absence of $200 \mu \mathrm{M}$ glyburide. Cell extracts were immunoblotted for caspase-1. Black arrowheads indicate procaspase-1, and white arrowheads mark the p20 subunit. (C) In vitro enzymatic activity of 1 IU mouse caspase-1 incubated with glyburide, glipizide, or the caspase-1 inhibitor Ac-YVAD-cmk. Data represent the mean \pm SD of triplicate samples from one out of three independent experiments. (D and E) ATPase activity of purified recombinant Cryopyrin and control eluates in the presence of $100 \mu \mathrm{M}$ glyburide, compound G1, or glipizide (D). (E) ATPase activity quantified by 
were approved by the Institutional Animal Care and Use Committee at Genentech. BMDMs were prepared as described previously (Lamkanfi et al., 2007). In brief, BMDMs were isolated from femurs of 6-12-wk-old mice and were cultured in Iscove's modified Dulbecco's medium containing 10\% heatinactivated FBS, $20 \% \mathrm{~L}$ cell-conditioned medium, $100 \mathrm{U} / \mathrm{ml}$ penicillin, and $100 \mathrm{mg} / \mathrm{ml}$ streptomycin at $37^{\circ} \mathrm{C}$ in a humidified atmosphere containing $5 \%$ $\mathrm{CO}_{2}$. After 5-7 d of incubation, cells were collected and plated in 6- or 24well plates in Iscove's modified Dulbecco's medium containing 10\% heatinactivated FBS and $100 \mathrm{mg} / \mathrm{ml}$ thymidine and antibiotics. Macrophages were cultured for an additional $24 \mathrm{~h}$ before use.

\section{LPS-induced endotoxemia}

8-wk-old male C57BL/6 mice (Charles River) were maintained in microisolator cages and received food and water ad libitum according to the American Association of Laboratory Animal Care guidelines. Mice were randomly divided into two groups ( $n=10 /$ group). The mice were injected intraperitoneally bid daily with $500 \mathrm{mg} / \mathrm{kg}$ glyburide or the formulation vehicle (DMSO/10\% HP-b-CD [2.5:97.5]) in $360 \mu$ PBS. $4 \mathrm{~h}$ after the first dosing, endotoxic shock was induced by intraperitoneal injection of $18 \mathrm{mg} / \mathrm{kg}$ LPS (Escherichia coli O111:B4; Sigma-Aldrich). Mice were monitored hourly for survival up to $36 \mathrm{~h}$. Differences in group survival were analyzed with the Kaplan-Meier test. $P<0.05$ was considered statistically significant.

\section{Patients}

The University of California San Diego Human Research Protection Program Committee approved this study, and informed consent was obtained from all subjects. Three related patients with FCAS (L353P mutation) and five normal controls were included. The FCAS patients had a classical clinical presentation, met diagnostic criteria, and were being treated with Rilonacept, an IL-1 $\beta$ inhibitor approved by the Food and Drug Administration, but held their dose for $>2$ wk before the experiment.

\section{Preparation of human adherent monocytes}

Venous blood was drawn into EDTA/Vacutainer tubes (BD) early in the morning when FCAS patients are generally least symptomatic. PBMC fractions were collected and resuspended in serum-free media and transferred to 24-well plates at a concentration of $1 \times 10^{6} / \mathrm{ml}$. Cells were incubated for $4 \mathrm{~h}$ at $37^{\circ} \mathrm{C}$, and nonadherent cells were removed leaving adherent monocytes as previously described (Rosengren et al., 2007).

\section{Bacteria, ligands, and inhibitors}

S. enterica serovar typhimurium strain SL1344 was provided by D. Monack (Stanford University, Palo Alto, CA). Single colonies were inoculated into $3 \mathrm{ml}$ of brain-heart infusion medium and grown overnight at $30^{\circ} \mathrm{C}$ with shaking. Anthrax lethal factor and protective antigen (List Biological Laboratories) were used at $10 \mathrm{\mu g} / \mathrm{ml}$. Ultrapure LPS, lipid A, lipoteichoic acid, peptidoglycan, and Pam3-CSK4 (InvivoGen) were used at $10 \mu \mathrm{g} / \mathrm{ml}$. ATP (Roche) was used at $5 \mathrm{mM}$, and nigericin (Sigma-Aldrich) was used at a final concentration of $20 \mu \mathrm{M}$. Glyburide, glipizide, and calmidazolium were obtained from Sigma-Aldrich and used at the indicated concentrations. Compounds G1-G4 were purchased from Ryan Scientific. DOTAP was obtained from Roche and used according to the manufacturer's instructions. Silicia (Min-U-Sil 5) was provided by US Silica, and H-LL-OMe was purchased from Chem-Impex International. Infection and stimulation of BMDMs were performed as described in Figs. 1-5.

\section{Microscopy}

Bright-field and fluorescence microscopy were performed in culture media at room temperature under a long-distance Plan Neofluar 20x/0.4 Ph2 Korr objective (Carl Zeiss, Inc.) on a microscope (Axiovert 200M; Carl Zeiss, Inc.) equipped with a charge-coupled device digital camera (Axiocam; Carl Zeiss, Inc.) and AxioVision software (Rel.4.6; Carl Zeiss, Inc.). For dye uptake assays, $2 \mu \mathrm{M}$ YoPro-1 (Invitrogen) was present 10 min before macrophages were stimulated with ATP for 5 min. Fluorescence signals in digital black and white fluorographs were artificially colored green with
Photoshop (Adobe). Macrophage membrane damage was measured with a Live/Dead assay (Invitrogen).

\section{Cytokines, antibodies, and Western blotting}

Human and mouse cytokines in culture supernatants were measured by enzyme-linked immunoabsorbent assay (R\&D Systems) and Luminex assay. Data were analyzed with Student's $t$ test, and $P<0.05$ was considered statistically significant. The caspase-1 antibody used for Western blotting was raised against recombinant mouse caspase-1 and was used as described previously (Lamkanfi et al., 2007). In brief, immunoblots were incubated overnight with the caspase- 1 antibody $(1: 1,000)$, and a goat anti-rabbit secondary antibody (Jackson ImmunoResearch Laboratories, Inc.) was used to detect proteins by enhanced chemiluminescence (Thermo Fisher Scientific).

\section{In vitro caspase- 1 activity assay}

In vitro caspase-1 activity was determined by incubating 1 IU recombinant mouse caspase-1 (BioVision) with $50 \mathrm{mM}$ fluorogenic caspase-1 substrate peptide Ac-WEHD-amc in $200 \mathrm{ml}$ CFS buffer $10 \mathrm{mM}$ Hepes, $\mathrm{pH} 7.4,220 \mathrm{mM}$ mannitol, $68 \mathrm{mM}$ sucrose, $2 \mathrm{mM} \mathrm{NaCl}, 2.5 \mathrm{mM} \mathrm{KH}_{2} \mathrm{PO}_{4}$, $0.5 \mathrm{mM}$ EGTA, $2 \mathrm{mM} \mathrm{MgCl}$, $0.5 \mathrm{mM}$ sodium pyruvate, $0.5 \mathrm{mM}$ L-glutamine, and $10 \mathrm{mM}$ DTT). The release of fluorescent 7-amino-4-methylcoumarin in the presence of the indicated concentrations of glyburide, glipizide, or the caspase-1 inhibitor Ac-YVAD-cmk was measured for $30 \mathrm{~min}$ at 1-min intervals by fluorometry (excitation at $360 \mathrm{~nm}$ and emission at $480 \mathrm{~nm}$ ) on a Cytofluor (PerSeptive Biosystems), and the maximal rate of increase in fluorescence was calculated $(\Delta \mathrm{F} / \mathrm{min})$

\section{ATPase assay}

ATP hydrolysis was measured by visualizing the conversion of $\alpha-\left[{ }^{32} P\right]$ ATP to $\left.\alpha-{ }^{32} \mathrm{P}\right] A D P$ using TLC. A total of $5 \mu$ purified Cryopyrin-Flag was incubated with $0.1 \mu \mathrm{M} \alpha-[32 \mathrm{P}]$ ATP $(3,000 \mathrm{Ci} / \mathrm{mmol}$; PerkinElmer) in a total volume of $20 \mathrm{\mu l}$ reaction buffer $(25 \mathrm{mM}$ Tris- $\mathrm{HCl}, \mathrm{pH} 7.5,150 \mathrm{mM} \mathrm{NaCl}, 10 \mathrm{mM}$ $\mathrm{MgCl}_{2}, 1 \mathrm{mM}$ DTT, $1 \mathrm{mM}$ EDTA, and EDTA-free Complete protease inhibitor cocktail tablets) containing $100 \mu \mathrm{M}$ glyburide, compound G1, glipizide, or vehicle control (DMSO) for $2 \mathrm{~h}$. The reaction was quenched by adding an equal volume of TLC development solvent (1 $\mathrm{M}$ formic acid and $0.5 \mathrm{M} \mathrm{LiCl}$ ). A total of $2 \mu$ reaction mixture was spotted on a polyethyleneimine cellulose TLC plate and developed with $1 \mathrm{M}$ formic acid with $0.5 \mathrm{M}$ $\mathrm{LiCl}$ in a TLC chamber. The TLC plate was exposed to x-ray film or used for quantification with a phosphoimager (Typhoon Trio; GE Healthcare).

\section{Online supplemental material}

Fig. S1 shows that LPS+ATP-induced caspase-1 activation and macrophage death are glyburide sensitive and, unlike LPS+nigericin, require the $\mathrm{P} 2 \mathrm{X}_{7}$ receptor. Fig. S2 shows that LPS+H-LL-OMe- and LPS+silica-induced caspase-1 activation and IL-1 $\beta$ secretion require Cryopyrin and TLR4 but not the $\mathrm{P} 2 \mathrm{X}_{7}$ receptor. Fig. S3 shows inhibition of caspase-1 activation by DIDS, immunopurification of recombinant Cryopyrin-Flag, and IL-1 $\beta$ secretion from FCAS monocytes. Online supplemental material is available at http://www.jcb.org/cgi/content/full/jcb.200903124/DC1.

We thank Andres Paler Martinez, Karen O'Rourke, Xingrong Liu, Yvonne Franke, Matt McGeough, and Carla Pena for technical support, Dr. Elizabeth McNally (University of Chicago, Chicago, IL) for SUR2 $2^{-1-}$ femurs, Dr. Alan Tall (Columbia University, New York, NY) for $\mathrm{Abcal}^{-/-}, \mathrm{Abcg}^{-/-}$, and

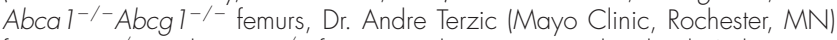
for Kir6. $1^{-1-}$ and Kirb. $2^{-/-}$femurs, and Dr. Peter Vandenabeele IGhent University, Ghent, Belgium) for caspase-1 antibody.

M. Lamkanfi, S. Misaghi, A.C. Vitari, A. Fedorova, K. Deshayes, W.P. Lee, and V.M. Dixit are employees and/or shareholders of Genentech.

Submitted: 23 March 2009

Accepted: 3 September 2009

phosphoimaging. Data represent the mean \pm SD of triplicate samples from one out of three independent experiments. (F) Adherent monocytes from FCAS patients $(n=3)$ were stimulated with $100 \mathrm{ng} / \mathrm{ml}$ LPS $(4 \mathrm{~h})$ and treated with $5 \mathrm{mM} \mathrm{ATP}(30 \mathrm{~min})$ in the presence of vehicle controls or $100 \mu M$ compound G1 or glipizide before IL-1 $\beta$ levels in culture supernatants were determined. Data represent the mean \pm SD of triplicate samples. (G) Adherent monocytes from FCAS patients $(n=3)$ were cultured at $32^{\circ} \mathrm{C}$ for $12 \mathrm{~h}$ in the presence of vehicle controls or $100 \mu \mathrm{M}$ compound G1 or glipizide. IL-1 $\beta$ levels were determined in culture supernatants. Data represent the mean \pm SD of triplicate samples. $(\mathrm{H})$ Protection against LPS-induced lethality in C57BL/6 mice $(n=10)$ injected intraperitoneally bid daily with $500 \mathrm{mg} / \mathrm{kg}$ glyburide or formulation vehicle. Results are representative of two independent experiments. 


\section{References}

Aguilar-Bryan, L., C.G. Nichols, S.W. Wechsler, J.P. Clement IV, A.E. Boyd III, G. González, H. Herrera-Sosa, K. Nguy, J. Bryan, and D.A. Nelson. 1995. Cloning of the beta cell high-affinity sulfonylurea receptor: a regulator of insulin secretion. Science. 268:423-426. doi: $10.1126 /$ science. 7716547

Ashcroft, F.M. 2005. ATP-sensitive potassium channelopathies: focus on insulin secretion. J. Clin. Invest. 115:2047-2058. doi:10.1172/JCI25495

Boyden, E.D., and W.F. Dietrich. 2006. Nalp1b controls mouse macrophage susceptibility to anthrax lethal toxin. Nat. Genet. 38:240-244. doi:10.1038/ng 1724

Cassel, S.L., S.C. Eisenbarth, S.S. Iyer, J.J. Sadler, O.R. Colegio, L.A. Tephly, A.B. Carter, P.B. Rothman, R.A. Flavell, and F.S. Sutterwala. 2008. The Nalp3 inflammasome is essential for the development of silicosis. Proc. Natl. Acad. Sci. USA. 105:9035-9040. doi:10.1073/pnas.0803933105

Clement, J.P. IV, K. Kunjilwar, G. Gonzalez, M. Schwanstecher, U. Panten, L. Aguilar-Bryan, and J. Bryan. 1997. Association and stoichiometry of K(ATP) channel subunits. Neuron. 18:827-838. doi:10.1016/ S0896-6273(00)80321-9

Dostert, C., V. Pétrilli, R. Van Bruggen, C. Steele, B.T. Mossman, and J. Tschopp. 2008. Innate immune activation through Nalp3 inflammasome sensing of asbestos and silica. Science. 320:674-677. doi:10.1126/science.1156995

Duncan, J.A.,D.T. Bergstralh,Y.Wang, S.B.Willingham,Z.Ye,A.G.Zimmermann, and J.P. Ting. 2007. Cryopyrin/NALP3 binds ATP/dATP, is an ATPase, and requires ATP binding to mediate inflammatory signaling. Proc. Natl. Acad. Sci. USA. 104:8041-8046. doi:10.1073/pnas.0611496104

Halle, A., V. Hornung, G.C. Petzold, C.R. Stewart, B.G. Monks, T. Reinheckel, K.A. Fitzgerald, E. Latz, K.J. Moore, and D.T. Golenbock. 2008. The NALP3 inflammasome is involved in the innate immune response to amyloid-beta. Nat. Immunol. 9:857-865. doi:10.1038/ni.1636

Hamon, Y., M.F. Luciani, F. Becq, B. Verrier, A. Rubartelli, and G. Chimini. 1997. Interleukin-1beta secretion is impaired by inhibitors of the Atp binding cassette transporter, ABC1. Blood. 90:2911-2915.

Hoffman, H.M., J.L. Mueller, D.H. Broide, A.A. Wanderer, and R.D. Kolodner. 2001. Mutation of a new gene encoding a putative pyrin-like protein causes familial cold autoinflammatory syndrome and Muckle-Wells syndrome. Nat. Genet. 29:301-305. doi:10.1038/ng756

Hornung, V., F. Bauernfeind, A. Halle, E.O. Samstad, H. Kono, K.L. Rock, K.A. Fitzgerald, and E. Latz. 2008. Silica crystals and aluminum salts activate the NALP3 inflammasome through phagosomal destabilization. Nat. Immunol. 9:847-856. doi:10.1038/ni.1631

Kanneganti, T.D., N. Ozören, M. Body-Malapel, A. Amer, J.H. Park, L. Franchi, J. Whitfield, W. Barchet, M. Colonna, P. Vandenabeele, et al. 2006. Bacterial RNA and small antiviral compounds activate caspase-1 through cryopyrin/Nalp3. Nature. 440:233-236. doi:10.1038/nature04517

Kanneganti, T.D., M. Lamkanfi, Y.G. Kim, G. Chen, J.H. Park, L. Franchi, P. Vandenabeele, and G. Núñez. 2007. Pannexin-1-mediated recognition of bacterial molecules activates the cryopyrin inflammasome independent of Toll-like receptor signaling. Immunity. 26:433-443. doi:10.1016/ j.immuni.2007.03.008

Laliberte, R.E., J. Eggler, and C.A. Gabel. 1999. ATP treatment of human monocytes promotes caspase-1 maturation and externalization. J. Biol. Chem. 274:36944-36951. doi:10.1074/jbc.274.52.36944

Lamkanfi, M., and V.M. Dixit. 2009. Inflammasomes: guardians of cytosolic sanctity. Immunol. Rev. 227:95-105. doi:10.1111/j.1600-065X.2008.00730.x

Lamkanfi, M., A. Amer, T.D. Kanneganti, R. Muñoz-Planillo, G. Chen, P. Vandenabeele, A. Fortier, P. Gros, and G. Núñez. 2007. The Nod-like receptor family member Naip5/Bircle restricts Legionella pneumophila growth independently of caspase-1 activation. J. Immunol. 178:8022-8027.

Locovei, S., E. Scemes, F. Qiu, D.C. Spray, and G. Dahl. 2007. Pannexin 1 is part of the pore forming unit of the $\mathrm{P} 2 \mathrm{X}(7)$ receptor death complex. FEBS Lett. 581:483-488. doi:10.1016/j.febslet.2006.12.056

Ma, W., H. Hui, P. Pelegrin, and A. Surprenant. 2009. Pharmacological characterization of pannexin-1 currents expressed in mammalian cells. $J$. Pharmacol. Exp. Ther. 328:409-418. doi:10.1124/jpet.108.146365

Mariathasan, S., K. Newton, D.M. Monack, D. Vucic, D.M. French, W.P. Lee, M. Roose-Girma, S. Erickson, and V.M. Dixit. 2004. Differential activation of the inflammasome by caspase-1 adaptors ASC and Ipaf. Nature. 430:213-218. doi:10.1038/nature02664

Mariathasan, S., D.S. Weiss, K. Newton, J. McBride, K. O'Rourke, M. RooseGirma, W.P. Lee, Y. Weinrauch, D.M. Monack, and V.M. Dixit. 2006. Cryopyrin activates the inflammasome in response to toxins and ATP. Nature. 440:228-232. doi:10.1038/nature04515

Martinon, F., V. Pétrilli, A. Mayor, A. Tardivel, and J. Tschopp. 2006. Goutassociated uric acid crystals activate the NALP3 inflammasome. Nature. 440:237-241. doi:10.1038/nature04516
Marty, V., C. Médina, C. Combe, P. Parnet, and T. Amédée. 2005. ATP binding cassette transporter $\mathrm{ABC} 1$ is required for the release of interleukin-1beta by P2X7-stimulated and lipopolysaccharide-primed mouse Schwann cells. Glia. 49:511-519. doi:10.1002/glia.20138

Meyer, M., F. Chudziak, C. Schwanstecher, M. Schwanstecher, and U. Panten. 1999. Structural requirements of sulphonylureas and analogues for interaction with sulphonylurea receptor subtypes. Br. J. Pharmacol. 128:2734. doi:10.1038/sj.bjp.0702763

Miki, T., K. Nagashima, F. Tashiro, K. Kotake, H. Yoshitomi, A. Tamamoto, T. Gonoi, T. Iwanaga, J. Miyazaki, and S. Seino. 1998. Defective insulin secretion and enhanced insulin action in KATP channel-deficient mice. Proc. Natl. Acad. Sci. USA. 95:10402-10406. doi:10.1073/pnas.95.18.10402

Miki, T., M. Suzuki, T. Shibasaki, H. Uemura, T. Sato, K. Yamaguchi, H. Koseki, T. Iwanaga, H. Nakaya, and S. Seino. 2002. Mouse model of Prinzmetal angina by disruption of the inward rectifier Kir6.1. Nat. Med. 8:466-472. doi:10.1038/nm0502-466

Pelegrin, P., and A. Surprenant. 2006. Pannexin-1 mediates large pore formation and interleukin-1beta release by the ATP-gated $\mathrm{P} 2 \mathrm{X} 7$ receptor. EMBO J. 25:5071-5082. doi:10.1038/sj.emboj.7601378

Pelegrin, P., and A. Surprenant. 2007. Pannexin-1 couples to maitotoxin- and nigericin-induced interleukin-1beta release through a dye uptakeindependent pathway. J. Biol. Chem. 282:2386-2394. doi:10.1074/jbc. M610351200

Perregaux, D.G., P. McNiff, R. Laliberte, N. Hawryluk, H. Peurano, E. Stam, J. Eggler, R. Griffiths, M.A. Dombroski, and C.A. Gabel. 2001. Identification and characterization of a novel class of interleukin-1 post-translational processing inhibitors. J. Pharmacol. Exp. Ther. 299:187-197.

Riddle, M.C. 2003. Editorial: sulfonylureas differ in effects on ischemic preconditioning - is it time to retire glyburide? J. Clin. Endocrinol. Metab. 88:528-530. doi:10.1210/jc.2002-021971

Rosengren, S., J.L. Mueller, J.P. Anderson, B.L. Niehaus, A. Misaghi, S. Anderson, D.L. Boyle, and H.M. Hoffman. 2007. Monocytes from familial cold autoinflammatory syndrome patients are activated by mild hypothermia. J. Allergy Clin. Immunol. 119:991-996. doi:10.1016/j. jaci.2006.12.649

Schott, W.H., B.D. Haskell, H.M. Tse, M.J. Milton, J.D. Piganelli, C.M. ChoisyRossi, P.C. Reifsnyder, A.V. Chervonsky, and E.H. Leiter. 2004. Caspase-1 is not required for type 1 diabetes in the NOD mouse. Diabetes. 53:99_ 104. doi:10.2337/diabetes.53.1.99

Solle, M., J. Labasi, D.G. Perregaux, E. Stam, N. Petrushova, B.H. Koller, R.J. Griffiths, and C.A. Gabel. 2001. Altered cytokine production in mice lacking P2X(7) receptors. J. Biol. Chem. 276:125-132. doi:10.1074/jbc. M006781200

Stoller, D., R. Kakkar, M. Smelley, K. Chalupsky, J.U. Earley, N.Q. Shi, J.C. Makielski, and E.M. McNally. 2007. Mice lacking sulfonylurea receptor 2 (SUR2) ATP-sensitive potassium channels are resistant to acute cardiovascular stress. J. Mol. Cell. Cardiol. 43:445-454. doi:10.1016/j.yjmcc .2007.07.058

Sutterwala, F.S., Y. Ogura, M. Szczepanik, M. Lara-Tejero, G.S. Lichtenberger, E.P. Grant, J. Bertin, A.J. Coyle, J.E. Galán, P.W. Askenase, and R.A. Flavell. 2006. Critical role for NALP3/CIAS1/Cryopyrin in innate and adaptive immunity through its regulation of caspase-1. Immunity. 24:317327. doi:10.1016/j.immuni.2006.02.004

Yvan-Charvet, L., C. Welch, T.A. Pagler, M. Ranalletta, M. Lamkanfi, S. Han, M. Ishibashi, R. Li, N. Wang, and A.R. Tall. 2008. Increased inflammatory gene expression in $\mathrm{ABC}$ transporter-deficient macrophages: free cholesterol accumulation, increased signaling via toll-like receptors, and neutrophil infiltration of atherosclerotic lesions. Circulation. 118:18371847. doi:10.1161/CIRCULATIONAHA.108.793869 